\title{
Analisis Teori Kemampuan, Motivasi Kerja, Kepuasan Kerja terhadap Kinerja Perawat
}

\author{
Devia Lydia Putri, Budi Hartono \\ Fakultas Kesehatan Masyarakat, Universitas Muhammadiyah Jakarta \\ Email: deviaputri88@gmail.com
}

\begin{abstract}
Performance is influenced by ability, work motivation, job satisfaction, which become the common problems faced by organizational leaders. The right nursing process activities have not been carried out adequately by the nurses, which has an impact on the hospital occupancy rate. The high turnover data in 2017 was $18 \%$ compared to 2016 as much as 12\%.
\end{abstract}

This study was an analytical survey with quantitative approach, using a cross sectional design. Population was 89 people, in this study researchers used the entire population to be sample. Data analysis method was Partial Least Square (PLS).

The results showed that the variable Ability of Gibson's theory (2001) was able to explain as much as 90,8\% (goodness of fit), and the remaining 9,2\% could be found by indocators / variables outside the theory under study. Maslow's Work Motivation Variable (1943) is able to explain 80,1\% (goodness of fit), and the remaining 19,9\% can be found indicators / variables outside the theory under study. Nurse Performance Variables theory of Mondy and Noe (1990); Tsui, et, al. (1997) ; L. Mathis and John H. Jackson (2002) ; Simamora (2004) is able to explain $86,6 \%$ (goodness of fit), and the remaining $13,2 \%$ can be found indicators / variables outside the theory under study. Overall performance is influenced by ability and motivation, but job satisfaction has no effect. It is recommended that the hospital be carried out efforts to increase capacity, namely the ability to interact, conceptual abilities, and technical abilities, while for work motivation, namely physical, sense of security, compassion, self actualization and appreciation.

Keywords : Ability, Work Motivation, Job Satisfaction, Nurse Performance.

\section{PENDAHULUAN}

Kemajuan sebuah organisasi tidak akan lepas dari keberadaan serta pengaruh sumber daya manusia (SDM) yang ada di dalamnya. SDM menjadi motor utama organisasi dalam menjalankan segala kegiatannya dalam upaya mencapai tujuan. Sumber daya manusia adalah faktor sentral dalam satu organisasi. Jadi manusia merupakan faktor strategis dalam semua kegiatan organisasi. ${ }^{1}$

Perawat merupakan sumber daya manusia yang ikut mewarnai pelayanan kesehatan di rumah sakit, karena selain jumlahnya yang dominan, juga merupakan profesi yang memberikan pelayanan yang konstan dan terus menerus 24 jam kepada pasien setiap hari. Sehingga setiap upaya untuk meningkatkan kualitas pelayanan rumah sakit harus juga disertai upaya untuk meningkatkan kualitas pelayanan keperawatan salah satunya dengan peningkatan kinerja perawat. ${ }^{2}$

Progam pengendalian mutu pelayanan keperawatan di rumah sakit merupakan bagian penting dalam pelayanan keperawatan 
secara keseluruhan. Salah satu kegiatan pengendalian mutu pelayanan keperawatan dapat dilakukan dengan kegiatan supervisi yang terutama dilakukan oleh kepala ruangan. Penelitian Nainggolan (2010) di Ruang Rawat Inap Rumah Sakit Malahayati Medan, didapatkan bahwa terdapat pengaruh pelaksanaan supervisi kepala ruangan terhadap kinerja perawat pelaksana. ${ }^{3}$

Kinerja perawat yang baik merupakan jembatan dalam menjawab jaminan kualitas pelayanan kesehatan yang di berikan terhadap pasien baik yang sakit maupun sehat. Beberapa teori mengemukakan teori kinerja dipengaruhi oleh kemampuan, motivasi kerja, dan Kepuasan Kerja. ${ }^{4-7}$

Menurut Teori motivasi (1943) yang paling terkenal adalah teori hierarki kebutuhan, dengan pencetusannya Abraham Maslow. Menurut Maslow bahwa dalam setiap diri manusia terdapat hierarki dalam lima kebutuhan. ${ }^{4}$ Menurut Teori dua faktor dikembangan oleh Herzberg (1968) bersamasama dengan Mausner dan Snyderman. Mereka melakukan penelitian dengan bertanya pada subjek penelitian tentang waktu ia merasa paling puas terhadap pekerjaannya. Faktor intrinsik yaitu daya dorong yang timbul dari dalam diri masingmasing orang, dan faktor ekstrinsik yaitu daya dorong yang datang dari luar diri seseorang. ${ }^{8}$

Turnover dapat berupa pengunduran diri, perpindahan keluar unit organisasi, pemberhentian, atau kematian anggota organisasi. Penggantian karyawan atau keluar masuknya karyawan dari organisasi adalah suatu fenomena paling penting dalam kehidupan organisasi. ${ }^{9}$ Turnover intention merupakan permasalahan yang sering dihadapi oleh banyak organisasi, seperti salah satunya yaitu organisasi pada rumah sakit.

Rumah Sakit X merupakan perusahaan jasa dengan jumlah karyawan yang cukup besar yaitu 89 orang perawat yang diharapkan menghasilkan kinerja yang lebih baik. Khususnya dalam memberikan asuhan keperawatan berdasarkan proses keperawatan. Kinerja bawahan dipengaruhi oleh motivasi yang diharapkan dapat meningkatkan komitmen terhadap organisasi. Kenyataan menunjukkan bahwa kinerja perawat di rumah sakit tersebut saat ini masih dianggap belum optimal. Kegiatan proses keperawatan yang benar belum dilakukan secara memadai oleh para perawat sehingga berdampak pada tingkat hunian rumah sakit. Data turnover yang cukup tinggi tahun 2017 sebanyak 18\% dibandingkan tahun 2016 sebanyak $12 \%$.

Namun, sampai saat ini belum ada penelitian yang dilakukan oleh rumah sakit tersebut untuk menggali kemampuan, motivasi kerja, dan kepuasan kerja di ruang rawat inap dan gambaran kinerja perawat, sehingga belum dapat dilakukan upaya untuk meningkatkan kinerja layanan keperawatannya. Berdasarkan fenomena di atas, peneliti merasa tertarik untuk mengkaji lebih dalam tentang analisis teori antara kemampuan, motivasi kerja, kepuasan kerja terhadap kinerja perawat.

\section{METODE PENELITIAN}

Penelitian yang digunakan dalam penelitian ini adalah metode analitik dengan pendekatan kuantitatif dan rancangan cross sectional. Penelitian ini menjelaskan hubungan kausal sebab dan akibat melalui pengujian hipotesis pengaruh serta dampaknya kepada variabel terikat, sehingga mengeksplorasi hubungan yang komplek antara kemampuan, motivasi kerja, kepuasan terhadap kinerja perawat. Dalam penelitian ini bertujuan untuk mengetahui pengaruh tiga variabel laten yang berhubungan dengan indikator-indikatornya, variabel independen yaitu variabel kemampuan (X1), motivasi kerja (X2), kepuasan kerja (X3), variabel dependen yaitu variabel kinerja perawat (Y).

Pelaksanaan penelitian ini dilakukan di bulan April sampai Juni di Ruang Rawat Inap Rumah Sakit X tahun 2018. Penelitian ini mengambil seluruh populasi untuk dijadikan sampel berjumlah 89 orang sudah dapat dikatakan layak untuk digunakan dalam sebuah penelitian kuantitatif. Selain itu untuk analisis menggunakan SmartPLS cukup dibutuhkan sampel maksimal 100. 
Pengumpulan data dilakukan melalui penyebaran kuesioner dengan pemilihan responden menggunakan teknik non probability. Metode analisis data yang digunakan adalah Partial Least Square (PLS) dimana ada menilai outer model atau measurment model (termasuk di dalamnya uji kualitas data yang meliputi uji validitas dan reliabilitas), menilai inner model atau structural model, uji validitas model keseluruhan dengan goodness of fit, uji hipotesis serta pembahasannya. Pengujian hipotesis pada penelitian ini menggunakan pendekatan Structural Equation Model (SEM) berbasis Partial Least Square (PLS).

\section{HASIL DAN PEMBAHASAN}

Hasil penelitian menunjukkan model pengukuran, bootstraping dan path coefficient sebagaimana diuraikan berikut ini:

\section{Tabel 1. Rincian Measurement Model}

\begin{tabular}{lccc}
\hline \multicolumn{1}{c}{ Indikator } & Kode & $\begin{array}{c}\text { Loading } \\
\text { Factor }\end{array}$ & Keterangan \\
\hline $\begin{array}{l}\text { Variabel Kemampuan (Gibson, 2001) } \\
\text { Kemampuan }\end{array}$ & e1 & 0,971 & Valid \\
$\begin{array}{l}\text { Berinteraksi } \\
\text { Kemampuan }\end{array}$ & & & \\
$\begin{array}{l}\text { Konseptual } \\
\text { (Conceptual }\end{array}$ & e2 & 0,930 & Valid \\
$\begin{array}{l}\text { Ability) } \\
\text { Kemampuan } \\
\text { Teknis }\end{array}$ & e3 & 0,951 & Valid \\
\hline $\begin{array}{l}\text { Variabel Kemampuan, Dimensi } \\
\text { Intelektual (Robbins, 1996) }\end{array}$ & Kemampuan \\
$\begin{array}{l}\text { Kemampuan } \\
\text { Numeris }\end{array}$ & e4 & 0,983 & Valid \\
$\begin{array}{l}\text { Pemahaman } \\
\text { Verbal }\end{array}$ & e5 & 0,990 & Valid \\
$\begin{array}{l}\text { Visualisasi } \\
\text { Ruang }\end{array}$ & e9 & 0,984 & Valid \\
Ingatan & e10 & 0,950 & Valid \\
Varabel Kemampuan
\end{tabular}

Variabel Kemampuan, Dimensi Kemampuan

Fisik (Robbins, 1996)

\begin{tabular}{|c|c|c|c|}
\hline Kekuatan & $\mathrm{e} 12$ & 0,935 & Valid \\
\hline Kekuatan & e14 & 0,902 & Valid \\
\hline $\begin{array}{l}\text { Koordinasi } \\
\text { Tubuh }\end{array}$ & e17 & 0,940 & Valid \\
\hline Stamina & e19 & 0,949 & Valid \\
\hline \multicolumn{4}{|c|}{ ariabel Motivasi Kerja (Maslow, 1943) } \\
\hline $\begin{array}{l}\text { Fisik } \\
\text { (Fisiologic) }\end{array}$ & $\mathrm{e} 20$ & 0,916 & Valid \\
\hline $\begin{array}{l}\text { Rasa Aman } \\
\text { (Safety) }\end{array}$ & $\mathrm{e} 21$ & 0,866 & Valid \\
\hline
\end{tabular}

\begin{tabular}{|c|c|c|c|}
\hline Indikator & Kode & $\begin{array}{c}\text { Loading } \\
\text { Factor }\end{array}$ & Keterangan \\
\hline $\begin{array}{l}\text { Kasih Sayang } \\
\text { (Belonging Dan } \\
\text { Love) }\end{array}$ & $\mathrm{e} 22$ & 0,936 & Valid \\
\hline Aktualisasi Diri & $\mathrm{e} 23$ & 0,841 & Valid \\
\hline $\begin{array}{l}\text { Variabel Motivasi } \\
\text { Herzberg 1968) }\end{array}$ & Kerja & (Maslow, & 1943 Dan \\
\hline Penghargaan & e24 & 0,879 & Valid \\
\hline $\begin{array}{l}\text { Variabel Motivasi } \\
\text { (Herzberg, 1968) }\end{array}$ & i Kerja & a, Faktor & Intrinsik \\
\hline Prestasi & e25 & 0,876 & Valid \\
\hline $\begin{array}{l}\text { Tanggung } \\
\text { Jawab }\end{array}$ & $\mathrm{e} 27$ & 0,839 & Valid \\
\hline $\begin{array}{l}\text { Variabel Motivasi } \\
\text { (Herzberg, 1968) }\end{array}$ & Kerja, & Faktor & Ektrinsik \\
\hline Supervisi & e29 & 0,769 & Valid \\
\hline Kondisi Kerja & e30 & 0,805 & Valid \\
\hline $\begin{array}{l}\text { Hubungan } \\
\text { Interpersonal }\end{array}$ & e31 & 0,884 & Valid \\
\hline $\begin{array}{l}\text { Bayaran Dan } \\
\text { Keamanan }\end{array}$ & e32 & 0,820 & Valid \\
\hline $\begin{array}{l}\text { Kebijakan } \\
\text { Rumah Sakit }\end{array}$ & e33 & 0,746 & Valid \\
\hline
\end{tabular}

Variabel Kepuasan Kerja (Kreitner Dan

Kinicki, 2001)

Pemenuhan

Kebutuhan

(Need

e34 $\quad 0,984 \quad$ Valid

Fulfillment)

Pencapaian

Nilai (Value $\quad$ e36 $0,985 \quad$ Valid

Attainment)

$\begin{array}{llll}\text { Keadilan } & \text { e37 } & 0,980 & \text { Valid }\end{array}$

Variabel Kepuasan Kerja (Robbins, 1996)

Pekerjaan Yang

Secara Mental e39 $\quad 0,971 \quad$ Valid

Menantang

Gaji/Upah Yang e40 0,923 Valid

Pantas

e41 $\quad 0,724 \quad$ Valid

Yang

e4t $0,724-$ Valid

Mitra Kerja

$\begin{array}{llll}\text { Yang } & \text { e42 } & 0,963 & \text { Valid }\end{array}$

Mendukung

Variabel Kinerja Perawat (Mondy Dan Noe (1990) ; Tsui, Et, Al (1997) ; L. Mathis Dan John

H. Jackson (2002))

Kecepatan

Kerja (Work $\quad$ e44 $\quad 0,909 \quad$ Valid

Timetable)

Pengetahuan

Kerja (Job $\quad$ e45 $\quad 0,910 \quad$ Valid

Knowledge)

Kualitas Diri

(Personal

Qualities)

Kualitas Kerja e47 $\quad 0,947 \quad$ Valid 


\begin{tabular}{|c|c|c|c|}
\hline Indikator & Kode & $\begin{array}{c}\text { Loading } \\
\text { Factor }\end{array}$ & Keterangan \\
\hline \multicolumn{4}{|l|}{$\begin{array}{l}\text { (Qualitiy Of } \\
\text { Work) }\end{array}$} \\
\hline \multicolumn{4}{|c|}{ Variabel Kinerja Perawat (Simamora, 2004) } \\
\hline Tanggungjawab & $\mathrm{e} 48$ & 0,900 & Valid \\
\hline Kejujuran & e49 & 0,910 & Valid \\
\hline Kerjasama & $\mathrm{e} 50$ & 0,958 & Valid \\
\hline Kesetiaan & e51 & 0,898 & Valid \\
\hline Ketelitian & $\mathrm{e} 52$ & 0,938 & Valid \\
\hline Kecakapan & e53 & 0,937 & Valid \\
\hline Kepemimpinan & e54 & 0,906 & Valid \\
\hline \multicolumn{4}{|c|}{$\begin{array}{l}\text { Variabel Kinerja Perawat (Mondy dan Noe } \\
\text { (1990) ; Tsui, Et, Al (1997) ; L. Mathis dan John } \\
\text { H. Jackson (2002) ; dan Simamora (2004)) }\end{array}$} \\
\hline $\begin{array}{l}\text { Kedisiplinan } \\
\text { Kerja }\end{array}$ & e55 & 0,914 & Valid \\
\hline Inisiatif & e56 & 0,875 & Valid \\
\hline
\end{tabular}

Sumber : data diolah dari SmartPLS

Rincian measurement model bahwa diketahuinya jumlah indikator keseluruhan ada 56, jika dikatakan valid nilai loading faktor diatas $(>0,7)$, indikator yang valid sebanyak 44, dan sisanya indikator tidak valid yaitu kecepatan preceptual $(0,334)$, penalaran infuktif $(0,454)$, penalaran deduktif (459), kekuatan dinamis $(0,390)$, kekuatan statis (0,314), keluwesan extent $(0,353)$, keluwesan dinamis $(0,231)$, keseimbangan $(0,376)$, pekerjaan itu sendiri $(0,136)$, pertumbuhan dan perkembangan $(0,346)$, perbedaan (0,195), komponen genetik $(0,301)$, dan kesesuaian kepribadian dengan pekerjaan $(0,257)$.

Metode untuk menilai discriminant validity pada outer model adalah dengan melihat nilai composite reliability dari variabel indikator yang mengatur konstruk. Discriminant validity dikatakan baik jika bernilai di atas $0,7 .^{10}$ Semua variabel memiliki nilai composite reliability yang di atas 0,7 dengan spesifikasi kemampuan $(0,966)$, kemampuan intelektual $(0,988)$, kemampuan fisik $(0,963)$, motivasi kerja $(0,949)$, faktor intrinsik $(0,984)$, faktor ekstrinsik $(0,959)$, kepuasan kerja $(0,980)$, dan kinerja perawat $(0,986)$. Selanjutnya, semua variabel dilanjutkan ke tahap analisis berikutnya yaitu pengujian model struktural (inner model).

Pengujian inner model atau model struktural dilakukan untuk melihat signifikansi hubungan kontruk dan $R$-Square Model struktural di evaluasi dengan menggunakan uji $t$ untuk mengetahui signifikansi dari koefisien jalur parameter jalur struktural. $R$-Square untuk mengetahui pengaruh variabel laten eksogen terhadap variabel laten endogen apakah memiliki pengaruh yang subtantif. Nilai $R$-Square konstruk kepercayaan antara lain kemampuan sebesar 0,908, motivasi kerja sebesar 0,801, dan kinerja perawat sebesar 0,868 . Semakin tinggi $R$-Square, maka semakin besar variabel independen tersebut dapat menjelaskan variabel dependen, sehingga semakin baik persamaan struktural.

Untuk memvalidasi model secara keseluruhan, maka digunakan goodness of fit (GOF). GOF merupakan ukuran tunggal yang digunakan untuk memvalidasi performa gabungan antara model pengukuran (outer model) dan model struktural (inner model). Nilai GOF diperoleh dari $Q$-Square, Nilai $Q$ -

Square memiliki arti yang sama dengan Coefficient Determination (R-Square) pada analisis regresi, dimana semakin tinggi $Q$ Square, maka model dapat dikatakan semakin baik atau semakin Fit dengan data. Adapun hasil per-hitungan nilai $Q$-square adalah Q2 = $1-(1-\mathrm{R} 12)(1-\mathrm{R} 42)(1-\mathrm{R} 82)=$ $1-(1-0,9082)(1-0,8012)(1-0,8682)=$ 0,985 . Diperoleh nilai $Q$-Square sebesar 0,985 .

Hal ini menunjukkan besarnya keragaman dari data penelitian yang dapat dijelaskan oleh model penelitian adalah sebesar 98,5\%. Sedangkan sisanya sebesar $01,5 \%$ dijelaskan oleh faktor lain yang berada di luar model penelitian ini. Dengan demikian, dari hasil tersebut maka model penelitian ini dapat dinyatakan telah memiliki Goodness of Fit yang baik. Menurut Ghozali (2015) menyatakan bahwa Goodness of Fit merupakan ukuran mengenai ketepatan model dalam menghasilkan observed matrix kovarian. ${ }^{10}$ Nilai Goodness of Fit harus berkisar 0-1. Semakin mendekati angka 1, model semakin baik, dan angka > 0,90 adalah angka yang sering digunakan para peneliti untuk menilai kecocokan model berdasarkan nilai Goodness Of Fit. 
Berikut ini adalah tampilan hasil Bootstrapping dalam Gambar 2.

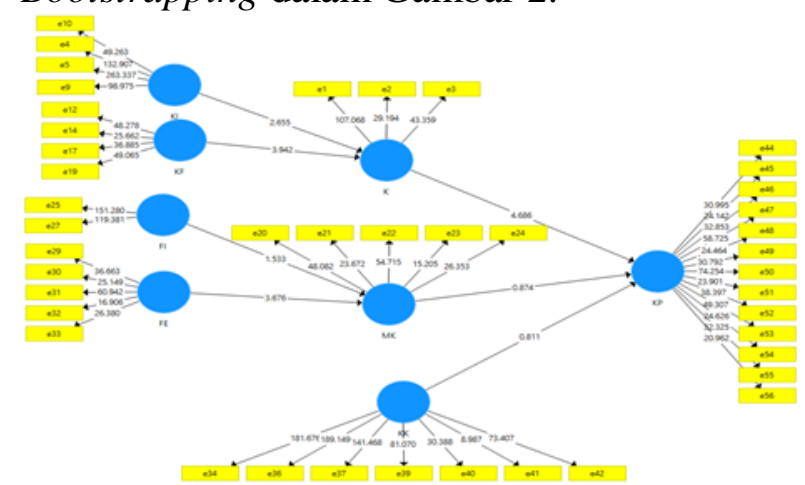

Gambar 2. Tampilan Hasil Bootstrapping Sumber : SmartPLS 3.0

Berdasarkan Gambar 2 menyatakan bahwa terlihat T-Statistics dimana dari variabel Kemampuan Intelektual (KI) terhadap kemampuan $(\mathrm{K})$ memiliki nilai tstatistics sebesar 2.655, variabel Kemampuan Fisik (KF) terhadap kemampuan (K) memiliki nilai t-statistics sebesar 3.942, variabel Kemampuan (K) terhadap Kinerja Perawa

(KP) memiliki nilai t-statistics sebesar 4.686, variabel Faktor Instrinsik (FI) terhadap Motivasi Kerja (MK) memiliki nilai t-statistics sebesar 1.533, variabel Faktor Ekstrinsik (FE) terhadap Motivasi Kerja (MK) memiliki nilai t-statistics sebesar 3.676, Motivasi Kerja (MK) terhadap Kinerja Perawat (KP) memiliki nilai t-statistics sebesar 0,861, dan variabel Kepuasan Kerja (KK) terhadap Kinerja Perawat (KP) memiliki nilai $t$-statistics sebesar 0,811 .

Untuk menguji hipotesis, dapat dinilai besarnya nilai t-statistics. Batas untuk menolak dan menerima hipotesis yang diajukan adalah $\pm 1,96$, apabila nilai $\mathrm{t}$ berada pada rentang nilai $>1,96$, maka hipotesis akan ditolak atau dengan kata lain menerima hipotesis nol (H0). Hasil estimasi t-statistics dapat dilihat pada path coefficient ( $t$ statistics) pada tabel 2.

Tabel 2. Hasil dari Path Coefficient (Mean, Standard deviation, T-Statistics, Value)

\begin{tabular}{lcccc}
\hline & $\begin{array}{c}\text { Original } \\
\text { sample }\end{array}$ & $\begin{array}{c}\text { Standard } \\
\text { deviation }\end{array}$ & $\begin{array}{c}\text { T- } \\
\text { Statistics }\end{array}$ & Value \\
\hline $\mathrm{KI} \rightarrow \mathrm{K}$ & 0,394 & 0,148 & 2,655 & 0,008
\end{tabular}

\begin{tabular}{lcccc}
\hline & $\begin{array}{c}\text { Original } \\
\text { sample }\end{array}$ & $\begin{array}{c}\text { Standard } \\
\text { deviation }\end{array}$ & $\begin{array}{c}\text { Statistics } \\
\text { St }\end{array}$ & Value \\
\hline $\mathrm{KF} \rightarrow \mathrm{K}$ & 0,570 & 0,145 & 3,942 & 0,000 \\
$\mathrm{~K} \rightarrow \mathrm{KP}$ & 0,720 & 0,154 & 4,686 & 0,000 \\
$\mathrm{FI} \rightarrow \mathrm{MK}$ & 0,275 & 0,179 & 1,533 & 0,126 \\
$\mathrm{FE} \rightarrow \mathrm{MK}$ & 0,631 & 0,172 & 3,676 & 0,000 \\
$\mathrm{MK} \rightarrow \mathrm{KP}$ & 0,139 & 0,159 & 0,874 & 0,382 \\
$\mathrm{KK} \rightarrow \mathrm{KP}$ & 0,091 & 0,112 & 0,811 & 0,418 \\
\hline
\end{tabular}

Sumber : Ouput smartPLS 3.0

\section{Kemampuan Intelektual Terhadap Kemampuan}

Hasil pengujian hubungan variabel kemampuan intelektual berhubungan terhadap kemampuan menunjukkan nilai koefisien jalur sebesar 0,394 dengan nilai tstatistics sebesar 2,655. Nilai tersebut lebih besar dari t-tabel $(1,960)$. Hasil ini berarti bahwa kemampuan intelektual memiliki hubungan bermakna dan positif terhadap kemampuan sebesar 40,2\%, dan value $(0,008)<(0,05)$ yang artinya ada hubung-an yang signifikan antara kemampuan intelektual terhadap kemampuan. Hal ini berarti hipotesis 1 diterima.

Menurut teori Robbins (2007), dimensi kemampuan intelektual adalah suatu kemampuan yang sangat dibutuhkan untuk melakukan berbagai aktivitas atau kegiatan mental berfikir, menalar dan memecahkan masalah. ${ }^{6}$ Dapat disimpulan bahwa kemampuan intelektual seorang perawat sangat berhubungan dengan kemampuan yang ada pada diri seorang perawat tersebut, karena akan memicu pada kemampuan di lingkungan dan menapatkan penilaian kinerja yang jauh lebih baik.

Kemampuan intelektual seorang perawat sangat berhubungan dengan kemampuan yang ada pada diri seorang perawat tersebut, karena akan memicu pada kemampuan di lingkungan dan menapatkan penilaian kinerja yang jauh lebih baik.

\section{Kemampuan Fisik Terhadap Kemampuan}

Hasil pengujian hubungan variabel kemampuan fisik berhubungan terhadap kemampuan menunjukkan nilai koefisien jalur sebesar 0,570 dengan nilai t-statistics sebesar 3,942. Nilai tersebut lebih besar dari t-tabel (1,960). Hasil ini berarti bahwa 
kemampuan fisik memiliki hubungan bermakna dan positif terhadap kemampuan sebesar $56,2 \%$, dan value $(0,000)<(0,05)$ yang artinya ada hubungan ya-ng signifikan antara kemampuan fisik terhadap kemampuan. Hal ini berarti hipotesis 2 diterima.

Hal ini sesuai dengan teori Robbins (1996), mengatakan bahwa kemampuan fisik meru-pakan kemampuan yang diperlukan untuk melakukan tugas yang menuntut stamina, kecekatan, kekuatan dan keterampilan fisik lainnya. ${ }^{6}$ Dapat disimpulan bahwa kemampuan fisik sangat berpengaruh terhadap kem-ampuan di sekitar lingkungan kerja karena dapat berpotensi mempengaruhi kinerja perawat tersebut.

Kemampuan fisik sangat berpengaruh terhadap kemampuan di sekitar lingkungan kerja karena dapat berpotensi mempengaruhi kinerja perawat tersebut.

\section{Kemampuan Terhadap Kinerja Perawat}

Hasil pengujian hubungan variabel kemam-puan berhubungan terhadap kinerja perawat menunjukkan nilai koefisien jalur sebesar 0,720 dengan nilai t-statistics sebesar 4,686. Nilai tersebut lebih besar dari t tabel $(1,960)$. Hasil ini berarti bahwa kemampuan memiliki hubungan bermakna dan positif terhadap kin-erja perawat sebesar $71,5 \%$, dan value $(0,000)<(0,05)$ yang artinya ada hubung-an yang signifikan antara kemampuan terhadap kinerja perawat. Hal ini berarti hipotesis 3 diterima.

Menurut Gibson (2001), bahwa kemampuan adalah sifat yang dibawa lahir atau dipelajari yang memungkinkan seseorang menyelesaikan pekerjaannya. ${ }^{5}$

Kemampuan (abilities) seseorang akan turut serta menentukan kinerja dan hasilnya. Kemampuan (abilities) ialah bakat yang melekat pada seseorang untuk melakukan sesuatu kegiatan secara fisik atau mental yang ia peroleh sejak lahir, belajar, dan dari pengalaman. Kemahiran (skill) biasanya diartikan kemampuan dalam menangani suatu tugas (pekerjaan) dengan menggunakan tenaga fisiknya tetapi ada juga yang berpendapat bahwa kemampuan dan kemahiran itu sama saja artinya. ${ }^{11}$

Kemampuan menunjukkan potensi orang untuk melaksanakan tugas atau pekerjaan. Kemampuan seseorang merupakan perwujudan dari pengetahuan dan ketrampilan yang dimiliki. Oleh sebab itu, Karyawan atau perawat yang memiliki kemampuan tinggi dapat menunjang tercapainya visi dan misi organisasi untuk segera maju dan berkembang pesat, guna mengantisipasi kompetisi global. Kemampuan yang dimiliki seseorang akan membuatnya berbeda dengan yang mempunyai kemampuan rata-rata atau biasa saja. Hal ini sesuai dengan penelitian sebelumnya di RS PHC Surabaya yang menunjukkan bahwa kemampuan atau keterampilah pegawai dalam bekerja memiliki pengaruh signifikan terhadap kepuasan kerja dan kinerja pegawai. ${ }^{12}$

\section{Faktor Intrinsik Terhadap Motivasi Kerja}

Hasil pengujian hubungan variabel faktor intrinsik berhubungan terhadap motivasi kerja menunjukkan nilai koefisien jalur sebesar 0,275 dengan nilai $t$-statistics sebesar 1,533. Nilai tersebut lebih kecil dari t-tabel (1,960). Hasil ini berarti bahwa faktor intrinsik memiliki hubungan tidak bermakna terhadap motivasi kerja sebesar $27,0 \%$, dan value $(0,126)>(0,05)$ yang artinya tidak ada hubungan yang signifikan antara faktor intrinsik terhadap motivasi kerja. Hal ini berarti hipotesis 3 tidak diterima.

Menurut teori Herzberg (1966), mengatakan bahwa faktor intrinsik merupakan daya dorong yang timbul dari dalam diri masing-masing orang, sehingga motivasi kerja yang didapatkan mempengaruhi kinerja pegawai di rumah sakit. $^{8}$

Kinerja seorang perawat dapat didorong dengan motivasi kerja yang ada di diri masing-masing perawat tersebut, sehingga semangat kerja yang di timbulkan dari dirinya sendiri mampu memberikan motivasi untuk dirinya sendiri dan menghasilkan kinerja yang baik.

\section{Faktor Ektrinsik Terhadap Motivasi}




\section{Kerja}

Hasil pengujian hubungan variabel faktor ekstrinsik berhubungan terhadap motivasi kerja menunjukkan nilai koefisien jalur sebesar 0,631 dengan nilai t-statistics sebesar 3,676. Nilai tersebut lebih besar dari t-tabel $(1,960)$. Hasil ini berarti bahwa faktor ekstrinsik memiliki hubungan bermakna dan positif terhadap motivasi kerja sebesar $63,6 \%$, dan nilai value $(0,000)<(0,05)$ yang artinya ada hubungan yang signifikan antara faktor ektrinsik terhadap motivasi kerja. Hal ini berarti hipotesis 5 diterima.

Menurut teori Herzberg (1966), mengatakan bahwa faktor ekstrinsik merupakan daya dorong yang datang dari luar diri seseorang khususnya dari tempat kerja, sehingga seorang perawat termotivasi dari lingkungan disekitar khususnya atasanya, jika atasan atau lingkungan disekitarnya memberikan dorongan atau motivasi kerja hal tersebut dapat meningkatkan atau mempengaruhi kinerja perawat jauh lebih baik dan memberikan pelayanan yang maksimal agar pasien tersebut merasa puas dan merasa dihargai. ${ }^{8}$

\section{Motivasi Kerja Terhadap Kinerja Perawat}

Hasil pengujian hubungan variabel motivasi kerja berhubungan terhadap kinerja perawat menunjukkan nilai koefisien jalur sebesar 0,138 dengan nilai t-statistics sebesar 0,861 . Nilai tersebut lebih kecil dari t-tabel $(1,960)$. Hasil ini berarti bahwa motivasi kerja memiliki hubungan tidak bermakna terhadap kinerja perawat sebesar $13,8 \%$, dan nilai $p$-value $(0,389)>(0,05)$ yang artinya tidak ada hubungan yang signifikan antara motivasi kerja terhadap kinerja perawat. Hal ini berarti hipotesis 6 tidak diterima.

Menurut teori Maslow (1943), yang mengatakan bahwa pada dasarnya semua manusia memiliki kebutuhan pokok. Ia menunjukkan dalam 5 tingkatan yang berbentuk piramid, orang memulai dorongan dari tingkatan terbawah. Lima tingkatan kebutuhan itu dikenal dengan sebutan hirarki kebutuhan, dimulai dari kebutuhan biologis dasar sampai motif pisikologis yang lebih kompleks yang hanya akan penting setelah kebutuhan dasar terpenuhi. Kebutuhan pada suatu peringkat paling tidak harus terpenuhi sebagian sebelum kebutuhan pada peringkat berikutnya menjadi penentu tindakan yang penting. ${ }^{4}$

Motivasi kerja berpengaruh positif dan signifikan terhadap kinerja pegawai. ${ }^{13}$ Temuan dalam penelitian ini dapat membantu manajemen dalam memutuskan skala prioritas dimaksud seperti mendahulukan peningkatan kinerja karyawan dibandingkan variabel lainnya.

Motivasi yang didapatkan di tempat kerja sangat mendukung untuk meningkatkan kinerja pegawat, Bila motivasi kerja rendah, maka untuk kinerja kerjanya akan rendah pula meskipun kemampuannya ada dan baik, serta peluangnya pun tersedia. Namun suasana kerja, hubungan antar tenaga kerja, kebijakan rumah sakit tidak dirasakan sesuai, maka "semangat" kerjanya menurun dengan hasil unjuk kerjanya kurang. Sebaliknya jika motivasi kerjanya besar, namun peluang untuk menggunakan kemampuankemampuannya tidak ada atau tidak diberikan, untuk kerjanya juga akan rendah. Kalau motivasi kerja tinggi, peluang ada, namun karena keahliannya dalam bidang tersebut tidak pernah ditingkatkan lagi, unjuk kerjanya juga tidak akan tinggi.

\section{Kepuasan Kerja Terhadap Kinerja Perawat}

Hasil pengujian hubungan variabel kepuasan kerja berhubungan terhadap kinerja perawat menunjukkan nilai koefisien jalur sebesar 0,091 dengan nilai $t$-statistics sebesar 0,811 . Nilai tersebut lebih kecil dari t-tabel $(1,960)$. Hasil ini berarti bahwa kepuasan kerja memiliki hubungan tidak bermakna terhadap kinerja perawat sebesar 10,9\%, dan value $(0,383)>(0,05)$ yang artinya tidak ada hubungan yang signifikan antara kepuasan kerja terhadap kinerja perawat. Hal ini berarti hipotesis 7 tidak diterima.

Menurut teori Kreitner Dan Kinicki (2001), mengatakan bahwa kepuasan kerja merupakan suatu efektifitas atau respons emosional terhadap berbagai aspek pekerjaan, sehingga dapat digambarkan 
kepuasan seorang pegawai mencangkup beberapa aspek yang berada di rumah sakit, seperti : Pemenuhan kebutuhan (Need fulfillment), Perbedaan (Discrepancies), Pencapaian nilai (Value attainment), Keadilan (Equity), dan Komponen genetik (Genetic components). ${ }^{7}$

Kepuasan seorang perawat baik dari luar maupun dari diri sendiri, mampu mempengaruhi nilai kinerja, sehingga mempengaruhi segala pekerjaan yang berada di rumah sakit.

\section{KESIMPULAN}

Model penelitian ini dapat dinyatakan telah memiliki Goodness Of Fit yang baik. Peningkatan kemampuan kinerja dapat dilakukan dengan suatu pendidikan khusus dan pelatihan kemampuan, bimbingan dan pengarahan. Peningkatan kesejahteraan pegawai, pelengkapan sarana dan prasarana pendukung, diadakannya sistem penghargaan atas prestasi yang dicapai pegawai dapat membuat pegawai termotivasi untuk memberikan yang terbaik bagi organisasi.

Dalam rangka meningkatkan Kinerja. Untuk meningkatkan kepuasan kerja diharapkan manajemen Ruang Rawat Inap RS. X dapat memperhatikan beban kerja dan stres kerja perawat dengan menciptakan suasana hubungan kerja yang tenang dan nyaman, memfasilitasi perawat untuk mengungkapkan aspirasi, keluhan dan masalah-masalah yang dihadapi perawat dalam bekerja sekaligus memberikan solusi atau jalan keluar atas masalah yang dihadapi.

\section{UCAPAN TERIMA KASIH}

Dalam rangka meningkatkan Kinerja. Untuk meningkatkan kepuasan kerja diharapkan manajemen Ruang Rawat Inap RS. X dapat memperhatikan beban kerja dan stres kerja perawat dengan menciptakan suasana hubungan kerja yang tenang dan nyaman, memfasilitasi perawat untuk mengungkapkan aspirasi, keluhan dan masalah-masalah yang dihadapi perawat dalam bekerja sekaligus memberikan solusi atau jalan keluar atas masalah yang dihadapi.

\section{DAFTAR PUSTAKA}

1. Rahmawati, Dkk. 2008. "Pengaruh Asimetri Informasi Terhadap Praktik Manajemen Laba Pada Perusahaan Perbankan Publik Yang Terdaftar Di Bursa Efek Jakarta". Tesis. Simposium Nasional Akuntansi IX. Padang.

2. Dewi \& Wiku. 2005. Hubungan Karakteristik Perawat, Isi Pekerjaan dan Lingkungan Pekerjaan Terhadap Kepuasan Kerja Perawat di Instalasi Rawat Inap RSUD

3. Nainggolan, M.J. (2010). Pengaruh Pelaksanaan Supervisi Kepala Ruang Terhadap Kinerja Perawat Pelaksana Di Rumah Sakit Malahayati Medan. Skripsi Fakultas Keperawatan Universitas Sumatra Utara . (online), Http://Repository.Usu.Ac.Id/Bitstream/12 3456789/20582/7/Cover.Pdf Di Akses Tanggal 05 Oktober 2017.

4. A.H Maslow. 1943. "A Theory Of Human Motivation", Psychological Review, Hal. 370; A.H Maslow, Motivation And Personality (New York; Harrper And Row, 1954).

5. Gibson, Charles H., 2001, Financial Reporting Analysis, 8th Edition, South Western College Publishing.

6. Robbins, S.P. 1996. Perilaku Organisasi, Konsep, Kontroversi Dan Aplikasi. Alih Bahasa : Hadyana Pujaatmaka. Edisi Keenam. Penerbit PT. Bhuana Ilmu Populer, Jakarta.

7. Kreitner R, \& Kinicki, A. 2001. Organizational Behavior, Fith dition, International Edition, Mc Graw-Hill Companies. Inc.

8. Herzberg F. The Motivation To Work. John Willey And Sons, Inc. New York; 1968.

9. Simamora, Henry. (2012). Manajemen Sumber Daya Manusia. Yogyakarta: Bagian Penerbitan Sekolah Tinggi Ilmu Ekonomi YKPN. Sugiyono. (2012).

10. Ghozali Imam. 2015. Structural Equation Modeling Metode Alternatif Dengan Partial Least Square (PLS). Semarang, Indonesia : Undip. 
11. Soehardi, 2003. Esensi Perilalu Organisasional. Bagian Penerbit Fakultas Ekonomi Sarjanawiyata Tamansiswa, Yogyakarta.

12. Nandini N, Rochmah TN. Penyebab Turnover Intention Pada Pegawai Instalasi Gizi Rumah Sakit PHC Surabaya. Jurnal Administrasi Kesehatan Indonesia. 2013;1.

13. Fardiansyah A, Muhith A, Saputra MH. Gambaran Tingkat Turnover Perawat, Motivasi, dan Kinerja Perawat di Rumah Sakit Islam Hasanah Mojokerto. Prosiding Seminar Nasional Hasil Penelitian dan Pengabdian Masyarakat Seri Ke-1 Tahun 2017. 2017 Dec 22(1):100-3. 